\title{
Análise da Política Educacional para as Pessoas com Deficiência Pós LDB 9.394/96: A Questão do Acesso à Educação Básica
}

\author{
Autor: José Roberto Carvalho \\ Nível: Mestrado (PPGE/UFPR) \\ Orientador: Profa. Dra. Taís Moura Tavares
}

\begin{abstract}
Este trabalho tem como objeto de análise o acesso das pessoas com deficiência à rede pública de ensino no marco da Lei de Diretrizes e Bases da Educação (Lei: 9.394/96), quando se marca o fato, até então inédito, da proposta de oferta de educação formal a essas pessoas preferencialmente na rede estatal de ensino. O trabalho aponta como pressuposto para a necessidade dessa política não se encerrar nos limites do Estado mínimo, considerado que essa política tende a se posicionar na contramão da redução dos gastos estatais. Essa dissertação, como fundamento da análise, estabelece uma contextualização dos fatores econômicos e políticos que determinaram as
\end{abstract}

políticas educacionais voltadas às pessoas com deficiência no Brasil, nos diferentes momentos históricos. Apresenta-se, também, uma sucinta descrição dos paradigmas de "inclusão responsável" e a entendida "inclusão radical", apontando insuficiências presentes nas duas versões. A partir desse quadro, analisam-se os dados de matrícula na educação especial, estabelecendo uma comparação no até então predominante atendimento isolado e no modelo de acesso à rede estatal de ensino. Essa investigação identifica, apesar dos muitos vieses ideológicos e limites percebidos nessa política, importantes avanços em termos de cobertura escolar. 